\title{
Unexpected Diversity of Feeding Modes among Chisel-Mouthed Ethiopian Labeobarbus (Cyprinidae)
}

\author{
Boris A. Levin ${ }^{1,2, *(\mathbb{D}}$, Aleksandra S. Komarova ${ }^{1}$, Oksana L. Rozanova ${ }^{3}$ and Alexander S. Golubtsov ${ }^{3}$ \\ 1 Papanin Institute for Biology of Inland Waters, Russian Academy of Sciences, 152742 Borok, Russia; \\ komarova.as90@yandex.ru \\ 2 Zoological Institute of Russian Academy of Sciences, 199034 St. Petersburg, Russia \\ 3 Severtsov Institute of Ecology and Evolution, Russian Academy of Sciences, 117071 Moscow, Russia; \\ shill.oks@mail.ru (O.L.R.); sgolubtsov@gmail.com (A.S.G.) \\ * Correspondence: borislyovin@gmail.com
}

Citation: Levin, B.A.; Komarova, A.S.; Rozanova, O.L.; Golubtsov, A.S. Unexpected Diversity of Feeding Modes among Chisel-Mouthed Ethiopian Labeobarbus (Cyprinidae) Water 2021, 13, 2345. https:// doi.org/10.3390/w13172345

Academic Editors: Kay Van Damme and Alexey A. Kotov

Received: 30 June 2021

Accepted: 20 August 2021

Published: 26 August 2021

Publisher's Note: MDPI stays neutral with regard to jurisdictional claims in published maps and institutional affiliations.

Copyright: (c) 2021 by the authors. Licensee MDPI, Basel, Switzerland. This article is an open access article distributed under the terms and conditions of the Creative Commons Attribution (CC BY) license (https:// creativecommons.org/licenses/by/ $4.0 /)$.

\begin{abstract}
Trophic resource partitioning is one of the main drivers of adaptive radiation. The evolutionary diversification of large African barbs, the genus Labeobarbus, seems to be related to mouth polymorphism. The chisel-mouthed or scraping phenotype has repeatedly evolved within Labeobarbus. At least five ecomorphs with a scraping mouth morphology were detected in the waters of the Ethiopian Highlands and can be provisionally classified into two groups: (i) "Varicorhinus"-like, and (ii) "Smiling"-like. Previously, all Labeobarbus with a scraping-mouth morphology were considered to be periphyton feeders. Using data on morphology, diet and stable isotope ratios ( $\mathrm{C}$ and $\mathrm{N})$, we addressed the question: does a scraping-mouth morphology predict feeding on periphyton? Our study revealed that five scraper ecomorphs exhibited three main feeding modes: (i) periphyton-eating, (ii) herbivory-detritivory, and (iii) insectivory. Two cases of the parallel divergence of sympatric ecomorphs with distinct feeding modes (herbivory-detritivory vs. insectivory) were revealed in two geographically isolated basins. A significant difference in $\delta 15 \mathrm{~N}$ values was detected among sympatric scraper ecomorphs. A periphytonophagous scraper was rich in $\delta 15 \mathrm{~N}$ values that are comparable with those in sympatric piscivorous fish. This data sheds light on the possibility of the utilization of periphyton as a protein-rich food by fishes.
\end{abstract}

Keywords: adaptive radiation; ecological speciation; fishes; Africa; trophic resource partitioning; stable isotopes

\section{Introduction}

Ecological diversification is a cornerstone of the process of adaptive radiation, considered as one of the main sources of biodiversity emergence [1-4]. The Ethiopian Highlands appears to be a hotspot of adaptive radiation in the cyprinid genera Labeobarbus, Enteromius and Garra, in both lacustrine and riverine environments [5-17]. Based on fish morphology, it was suggested that trophic resource partitioning was the main driver for these cyprinid radiations, and this has been proven for some lacustrine and riverine Labeobarbus assemblages [11,15].

Particular morphological traits (especially mouth shape and position, dentition, sieving apparatus and gut structure) can act as guides to fish trophic ecology [18-20]. Specifically, it is generally accepted that these cyprinids have a subterminal, often sectorial mouth, a cutting horny (keratinized) edge of the lower jaw, and a long gut scrape periphyton from submerged rocks and other substrates $[18,20,21]$. This type of scraping mouth structure, supplemented by an elongated gut, is found in many phylogenetically distant cyprinid lineages in North America (the genera Acrocheilus and Campostoma-[22], Asia (the genera Capoeta, Cyprinion, Garra, Chondrostoma, Labeo, Onychostoma, Scaphiodonichthys, Schizopygopsis, and Xenocypris-[20,23-26], and Africa (the genera Garra, Labeo, Labeobarbus and Varicorhinus-[21,27-30]. Along with the periphyton, such food items as macrophytes, 
detritus, insect larvae, macro- and microcrustaceans, and mollusks were reported for the European common nase, Chondrostoma nasus, the cyprinid scraper whose diet has been studied most comprehensively [25,31].

In Africa, in general, and in the Ethiopian Highlands, in particular, the cyprinids with a scraping head morphology belong to two distinct phylogenetic lineages: Labeonini (including Garra and Labeo) and Torini (including Labeobarbus and former Varicorhinus) in terms of Yang et al. [32,33]. The former lineage is beyond the scope of the present work, while phylogenetic relationships within the latter lineage are recently revised. Until recently, the African specialized scrapers were considered as belonging to the genus Varicorhinus, established by Rüppel (1835) for $V$. beso from the north of the Ethiopian Highlands. This genus encompassed 36 species $[34,35]$. There are, however, molecular data clearly proving the multiple origins of scraping morphologies within the African Torini lineage $[36,37]$. Therefore, the genus Varicorhinus was suggested to be monotypic [37] or even to be a synonym of the Labeobarbus $[29,38]$.

In the context of multiple emergences of the scraping morphology among the Labeobarbus species, the origin of this genus is of particular interest. Labeobarbus are evolutionary hexaploids with $2 n=150$ [39-43] with a complex genome originating via the hybridization of tetraploids (maternal Tor lineage) and diploids (paternal Cyprinion lineage), and then dispersed throughout Africa [33]. Thus, all Labeobarbus inherited the genomic template for building the scraping head morphology from the parental lineage, the genus Cyprinion being a highly specialized scraper. This is why the multiple proliferation of the scraping morphology among Labeobarbus species is not surprising. This occurs from the level of intraspecific variation to the most specialized (among African Torini) scraping morphology in L. beso [21,44,45].

It is noteworthy that all the radiating Labeobarbus assemblages from Ethiopian watersfrom Lake Tana and the middle reaches of four rivers (Didessa, Sore, Gojeb and Genale - [16] include or co-exist with the more- or less-specialized scraping congeneric form or forms [16]. The northern assemblages from Lake Tana and the Didessa River (both occurring in the Blue Nile basin) co-exist with the phylogenetically distant $L$. beso $[11,16,45]$. The apparently monophyletic and genetically distinct Labeobarbus gananensis/jubae complex from the Indian Ocean catchment in southeastern Ethiopia gave an origin to the assemblage in the middle reaches of the Genale River $[15,16,37]$. This assemblage includes two scraping forms that are genetically separated from the remaining sympatric Labeobarbus forms, and one of them is found beyond the limits of distribution of the other, trophically specialized, forms constituting the Genale assemblage [15]. Regarding the scraping forms from the Gojeb River (the enclosed Omo-Turkana basin) and the Sore River (the White Nile drainage) both in southwestern Ethiopia-we failed to distinguish them genetically (with mt-DNA markers, whereas nuclear DNA markers are as yet hardly studied because of hexaploidy) from the other sympatric forms in their assemblages, while the independent evolution of the Gojeb and Genale assemblages is rather evident [16].

As already mentioned, the Genale and Gojeb assemblages each include two scraping forms. The morphological differences between sympatric scraping forms from the two different assemblages look rather similar (Figure 1). The scrapers that were earlier designated as "scraper 1" in both assemblages [16] exhibit so-called Varicorhinus-like (V-like) morphology [21,45]: a rather straight cutting edge to the lower jaw, shortened snout and deep body. In the Genale River, this form is identified as L. jubae, the species originally described by Banister [46] as belonging to the genus Varicorhinus. The other scraping forms from the Genale and Gojeb exhibit the head morphology that is seemingly unique for the African Torini (Figure 1): a rather rounded cutting edge to the lower jaw, elongated snout and shallow body. Both forms were designated as "scraper 2" by Levin et al. [16], but such forms from the Genale were also designated as "smiling" by Levin et al. [15] and Golubtsov et al. [14]. The latter variant is accepted herein, and the morphologically similar form from the Gojeb is designated herein as "smiling-like" or S-like. 

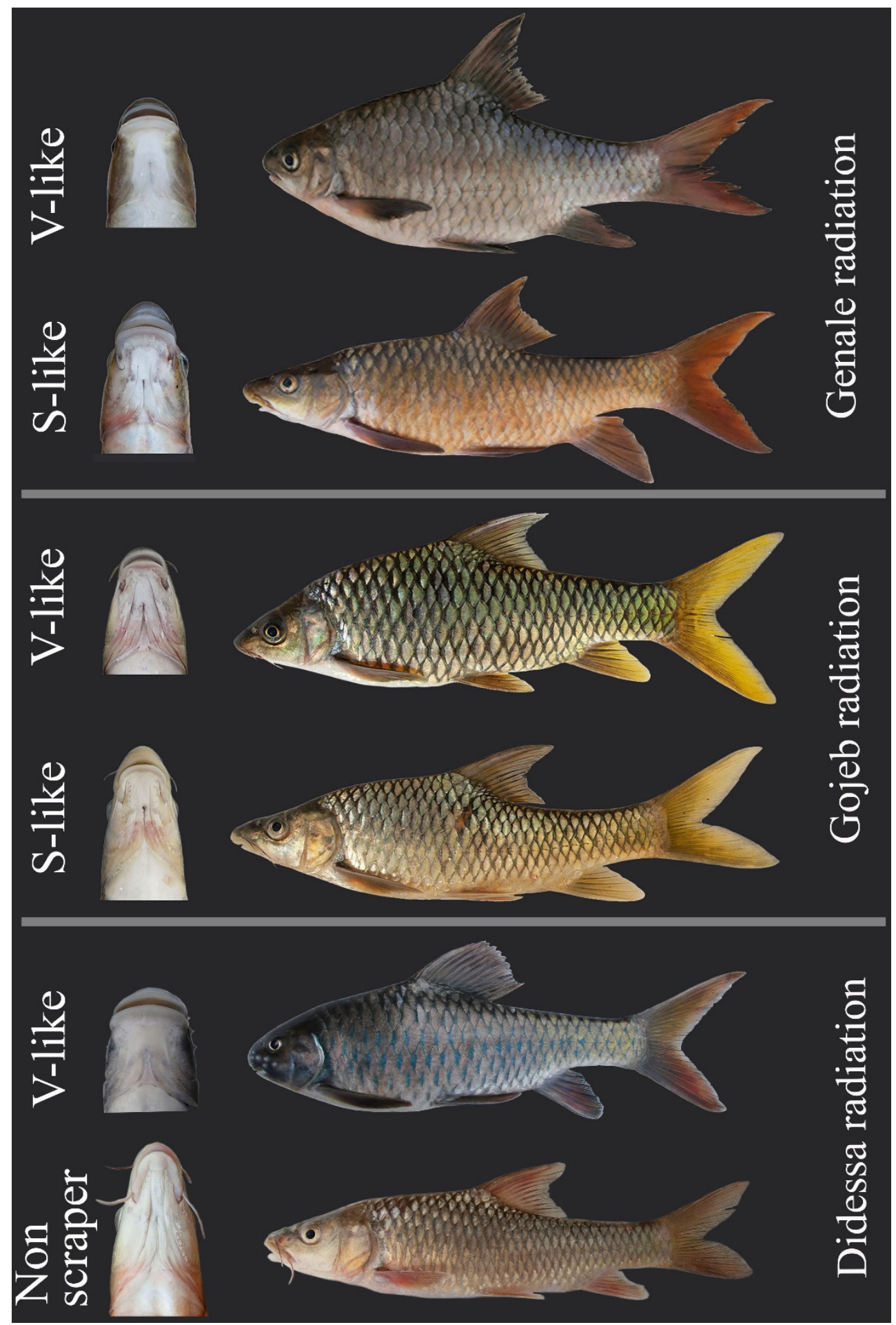

Figure 1. Mouth and lateral views of different scraping forms that evolved within the genus Labeobarbus, from three Ethiopian rivers: top, V-like (L. jubae) and S-like ("smiling") from the Genale; middle, V-like and S-like from the Gojeb; bottom, V-like (L. beso) and non-scraping forms (for comparison) from the Didessa. Both forms from Genale represent the L. gananensis complex, both forms from the Gojeb and the non-scraper from the Didessa represent the L. intermedius complex.

We have to note that the Varicorhinus-like forms in both the Genale and Gojeb rivers appear quite frequently in the catches; their prevalence is next to that of the omnivorous form with a generalized morphology. The smiling-like form is moderately prevalent in the Genale [14], while the smiling-like form is extremely rare in the Gojeb. 
The occurrence of the two distinct scraping forms of Labeobarbus in the Genale and Gojeb assemblages may indicate the availability of the different food resources exploited by these forms. Generally, the idea regarding the availability of different resources for the sympatric cyprinid scraping forms seems to be supported by the fact that two other lineages of scraping cyprinids-representing the genera Garra and Labeo, particularly the L. forsksalii group, in terms of Reid [47]—are found in sympatry with practically all the radiating Labeobarbus assemblages in Ethiopia; the only exclusion is an absence of Labeo in the Lake Tana basin [12,48].

The current study addresses the following questions: are there any differences in feeding modes between the scraping forms of Labeobarbus that constitute the radiating assemblages in the Ethiopian rivers? In the broader sense, are the diets of Labeobarbus with a scraping head morphology predictable, based on those morphological traits related to feeding? To answer these questions, we investigated feeding-related morphology, diet, and the stable isotope signatures of ${ }^{15} \mathrm{~N}$ and ${ }^{13} \mathrm{C}$ in five supposedly scraping forms and one nonscraping form from the Genale, Gojeb and Didessa rivers in southern and western Ethiopia.

\section{Materials and Methods}

\subsection{Study Area and Sampling}

The fish were sampled from three rivers in the Ethiopian Highlands, from three geographically separated drainages: (i) the Genale River in the Juba-Wabe-Shebelle basin, Indian Ocean catchment $\left(05^{\circ} 42^{\prime} 08^{\prime \prime} \mathrm{N} 39^{\circ} 32^{\prime} 39^{\prime \prime} \mathrm{E}\right)$; (ii) the Gojeb River in the Omo-Turkana basin, Ethiopian Rift Valley drainage $\left(07^{\circ} 15^{\prime} 15^{\prime \prime} \mathrm{N} 36^{\circ} 47^{\prime} 40^{\prime \prime} \mathrm{E}\right)$; (iii) the Didessa River, a tributary of the Blue Nile in the Atlantic Ocean catchment $\left(08^{\circ} 41^{\prime} 32^{\prime \prime} \mathrm{N} 36^{\circ} 24^{\prime} 52^{\prime \prime} \mathrm{E}\right)$. Each location (Figure 2) was sampled using gill and cast nets in March-April 2009 or March 2019 (Genale R.), February 2011 (Gojeb R.) and February-March 2011 (Didessa R.). Fish sampling was conducted under the umbrella of the Joint Ethiopian-Russian Biological Expedition (JERBE) with the permission of the National Fisheries and Aquatic Life Research Center (NFALRC) under the Ethiopian Institute of Agricultural Research (EIAR) and Ethiopian Ministry of Science and Technology (presently the Ministry of Innovation and Technology). Fish were killed with an overdose of an anesthetic, MS-222, and were first preserved in $10 \%$ formalin and then transferred to $70 \%$ ethanol for studying the morphology and gut content. Some fish were preserved with salt to make the dried bone preparations for subsequent morphological analysis. This approach has worked well for estimating the morpho-ecological diversification of the Labeobarbus ectomorphs [6,49]. Fish were photographed using a Canon EOS 50D camera (Canon Inc. Ota City, Tokyo, Japan). In total, 65-117 specimens were analyzed, depending on the type of analysis (Table 1). All specimens are deposited at the A.N. Severtsov Institute of Ecology and Evolution, Russian Academy of Sciences, Moscow, under the provisional labels of JERBE. The map of the sampling sites (Figure 2) was created in ArcGIS 10.2 (www.esri.com) (accessed on 08 August 2020). 


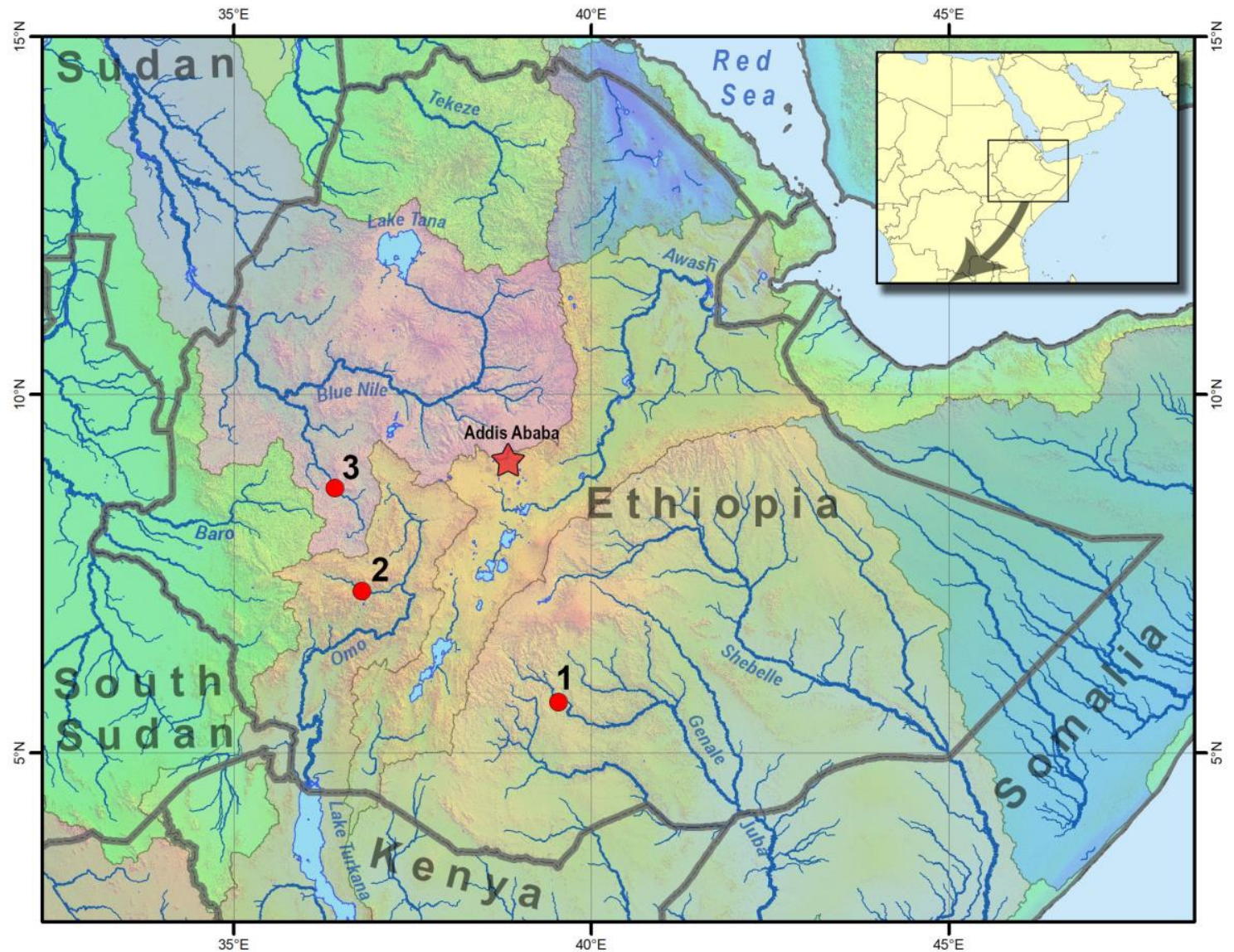

Figure 2. Map of sampling localities: 1-Genale River, 2-Gojeb River, and 3-Didessa River.

Table 1. Sample size of the studied ecomorphs.

\begin{tabular}{|c|c|c|c|c|c|}
\hline Ecomorphs (SL Range, mm) & $\begin{array}{c}\text { Gut } \\
\text { Length (n) }\end{array}$ & $\begin{array}{l}\text { Osteology } \\
\text { (n) }\end{array}$ & $\begin{array}{c}\text { Gill } \\
\text { Rakers (n) }\end{array}$ & $\begin{array}{c}\text { Stable } \\
\text { Isotopes (n) }\end{array}$ & $\begin{array}{c}\text { Diet } \\
\text { (n) }\end{array}$ \\
\hline \multicolumn{6}{|c|}{ Scrapers within L. gananensis/jubae complex-Genale River (Indian Ocean basin) } \\
\hline V-like (89-349) & 22 & 26 & 15 & 13 & 12 \\
\hline S-like (82-360) & 22 & 13 & 14 & 14 & 12 \\
\hline \multicolumn{6}{|c|}{ Scrapers within L. cf. intermedius complex-Gojeb River (Omo-Turkana basin) } \\
\hline V-like (142-361) & 40 & 28 & 23 & 32 & 17 \\
\hline S-like (251-256) & 2 & 1 & 1 & 2 & 1 \\
\hline \multicolumn{6}{|c|}{ L. beso and L. cf. intermedius_Didessa River (Blue Nile basin) } \\
\hline V-like scraper (L. beso) (65-230) & 21 & 17 & 16 & 24 & 20 \\
\hline $\begin{array}{c}\text { Non-scraper, omnivorous } \\
\text { ecomorph (L. cf. intermedius) } \\
(90-378)\end{array}$ & 10 & 8 & 9 & 23 & 3 \\
\hline Total & 117 & 85 & 78 & 108 & 65 \\
\hline
\end{tabular}

\subsection{Examination of Morphological Characters}

All fish were measured for standard length (SL) according to Hubbs and Lagler [50]. Upon preparation of the dried skeletons, the neurocranium and bones of the splanchnocranium were measured, following the scheme of Levin et al. [51], to estimate phenotypic relationships between the forms under consideration. In total, 28 characters from 85 individuals were estimated: $B L-$ basal skull length, SEth-width of the skull at the ethmoidalia lateralia, SSph — width of the skull at the processes of sphenotica, SPt—width of skull at the processes of pterotica, SFr-min - width of the skull at the maximally concave 
edges of frontalia, $H$-greatest depth of the neurocranium, HEth-depth of the skull at the level of the ethmoidalia lateralia, WBsoc - width of the basioccipitale plate, Eth-Sphthe distance between the edge of the ethmoidale laterale and the apex of the process of the sphenoticum, $\mathrm{Hm}$-length of the hyomandibulare, $\mathrm{WHm}$ - greatest width of the hyomandibulare, $\mathrm{HHm}$ - height of the hyomandibulare, Dff-length of the fifth ceratobranchiale, WDff — width of the fifth ceratobranchiale, $P m$-length of the praemaxillare, $H P m-p r$ - depth of the process of the praemaxillare, Pop-length of the praeoperculum, Wpop — width of the praeoperculum, Iop - length of the interoperculum, $M x$-length of the maxillare, $h M x$ - minimum depth of the maxillare, De-length of the dentale, HDe-depth of the dentale with coronoid process, Urh-length of the urohyale, WUrh-width of the urohyale, $\mathrm{Pal}$-length of the palatinum, WPal —width of the palatinum, $\mathrm{HPal}$ - height of the palatinum. Measurements were made using a digital caliper to the nearest $0.1 \mathrm{~mm}$ by one operator for the purposes of consistency, as recommended by Mina et al. [52]. Gut length (GL) was measured with a ruler (to the nearest $1 \mathrm{~mm}$ ). Gill arches were stained with Alizarin red, and gill rakers (GR) on both the lower and upper arches were counted together using a binocular microscope (Leica EZ4D, Wetzlar, Germany).

\subsection{Diet and Stable Isotopes}

Gut contents were dried on absorbent paper and each dietary item was weighed to the nearest $0.1 \mathrm{mg}$. The index of relative significance (IR) [53,54] was calculated as follows: $\mathrm{IR}=\left(\mathrm{Fi} \times \mathrm{Pi} / \sum \mathrm{Fi} \times \mathrm{Pi}\right) \times 100 \%$, where $\mathrm{Fi}=$ frequency of occurrence of each food species, $\mathrm{Pi}=$ a part by weight; the value of $\mathrm{i}$ itself changes from 1 to $\mathrm{n}(\mathrm{n}=$ the part of food organisms in the food bolus). In total, 65 individuals were investigated for diet.

White muscle tissue from the dorsal side of the body under the dorsal fin was sampled from freshly collected specimens. White muscle samples were dried at $60^{\circ} \mathrm{C}$ for subsequent stable isotope analyses. Samples were weighed using a Mettler Toledo MX5 analytical balance (Mettler Toledo, Columbus, OH, United States) with $2 \mu \mathrm{g}$ accuracy and wrapped in tin capsules. The weight of fish tissue samples varied from 250 to $500 \mu \mathrm{g}$. Stable isotope analysis was conducted at the Joint Usage Center of the A.N. Severtsov Institute of Ecology and Evolution (RAS), Moscow. Briefly, a Thermo Delta V Plus continuous-flow IRMS was coupled with an elemental analyzer (Flash 1112) and equipped with a Thermo No-Blank device. The isotopic composition of $\mathrm{N}$ and $\mathrm{C}$ was expressed in a $\delta$ notation relative to the international standards (atmospheric nitrogen and VPDB, respectively): $\delta \mathrm{X}(\%)=[($ Rsample $/$ Rstandard $)-1] \times 1000$, where $R$ is the ratio of the heavier isotope to the lighter. The samples were analyzed with a reference gas calibrated against the International Atomic Energy Agency (IAEA) reference materials USGS 40 and USGS 41 (glutamic acid). The measurement accuracy was $\pm 0.2 \delta$ units. Along with the isotopic analysis, nitrogen and carbon content (as \%), and $\mathrm{C} / \mathrm{N}$ ratios were determined in all samples. In total, 108 white muscle samples were analyzed.

Four freshly collected stable isotope samples of $L$. beso were combined with 20 muscle samples obtained from preserved individuals (in 10\% formalin in the field, with subsequent transfer to $70 \%$ ethanol in the laboratory) collected from the same locality. The difference between freshly collected and preserved samples was not significant for both $\delta^{13} \mathrm{C}$ (Mann-Whitney U test, $\left.p=0.5055\right)$ and $\delta^{15} \mathrm{~N}$ values (Mann-Whitney U test, $p=0.3657$ ). Nevertheless, for the lipid normalization of preserved samples, we applied the equation $\left[\delta^{13} \mathrm{C}\right.$ corrected $=\delta^{13} \mathrm{C}$ untreated $\left.-3.32+0.99 \cdot \mathrm{C}: \mathrm{N}\right]$, as suggested by Post et al. [55], to correct $\delta^{13} \mathrm{C}$ values because the preserved samples had $\mathrm{C} / \mathrm{N}$ (mass/mass) values higher than 3.50, compared to those in freshly collected samples $(\mathrm{C} / \mathrm{N}$ mass $/$ mass average $=3.24$, $\mathrm{SD}=0.07)$. After correction of the $\delta^{13} \mathrm{C}$ values for the preserved samples, the difference between the freshly collected and preserved samples remained insignificant (Mann-Whitney $\mathrm{U}$ test, $p=0.2862$ ). 


\section{Statistical Analysis}

Several R packages realized in R-studio v.1.2.5033 [56] were used for statistical analyses and plot construction: the summarytools library [57] was used for obtaining basal descriptive statistics, the ggplot2 library [58] was used to calculate Pearson correlation as well as to build violin boxplots, the posthoc.kruskal.dunn.test function in the PMCMR library [59] was applied for the Kruskal-Wallis post hoc Dunn's test, the FSA library [60] was applied for the Mann-Whitney U test, and the prcomp function [56] was used for the principal component analysis (PCA) and for plotting the results. All measurements were divided by neurocranium basal length $(B L)$; these proportions were used for PCA. Data were scaled.

\section{Results}

\subsection{Morphology}

V-like and S-like scrapers significantly diverged between each other in the space of PC1 and PC2 in osteological character within each sympatric pair, i.e., in the Genale and Gojeb rivers (Figure 3A,B). The pair from the Didessa River (L. beso/non-scraper omnivorous $L$. cf. intermedius) also demonstrates a high divergence in skull proportions (Figure 3C). PC1 explained $40-61 \%$ of the variance, while PC2 explained only $15-17 \%$. The eigenvectors of the 10 most loaded characters for PC1 and PC2 are given in Tables S1-S3.
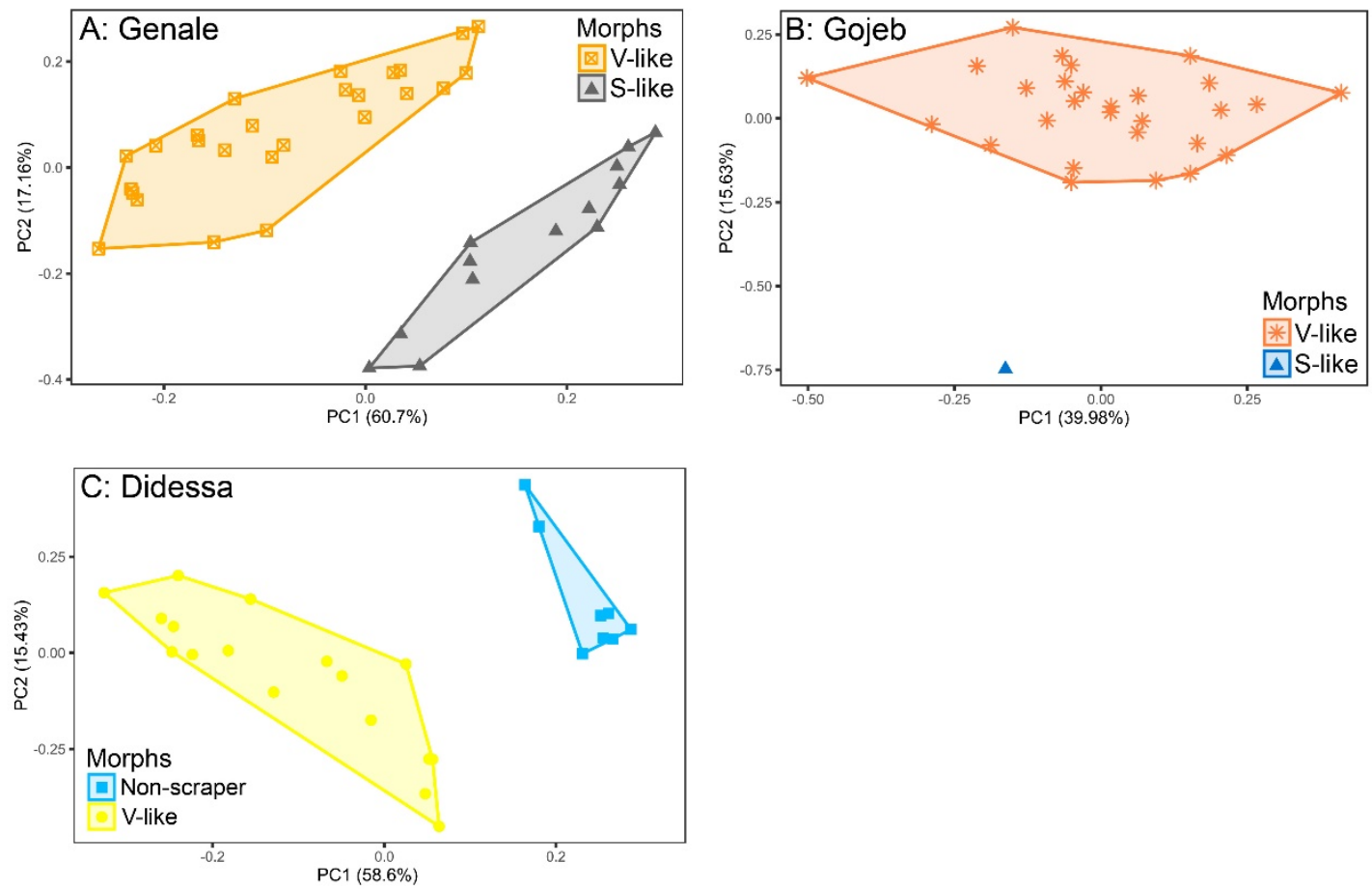

Figure 3. PCA of skull divergence between sympatric pairs from three riverine radiations: (A) Genale, (B) Gojeb, and (C) Didessa.

\subsection{Gut Length}

All scrapers had a gut length varying roughly within the range of 2.5-7 SL. The nonscraper, omnivorous ecomorph of L. intermedius from the Didessa river had an intermediate gut length of about 3.2 SL. The V-like scraper had a longer gut than the S-like scraper in both Genale and Gojeb radiations (Figure 4A) with significant differences for the Genale (means were $440 \%$ SL vs. $251 \%$ SL for V-like and S-like, respectively; $p<0.01$ ). The Didessa pair was significantly $(p=0.02)$ divergent in gut length, having $479 \%$ SL (V-like) vs. $334 \%$ SL (non-scraper) (Figure 4A). Simultaneously, significant divergences in gut length were detected between non-sympatric scraper ecomorphs; this is especially true for the most divergent V-like specimens from the Didessa with the longest gut (up to 7 body 
lengths-Figure 4A). Gut length (\% SL) in all ecomorphs, except for the S-like type from the Genale, was positively correlated with body length, sometimes significantly (see the values for the Pearson correlation in Figure S1). The gut length of Genale's S-like scraper had a negative although non-significant correlation with body length. Nevertheless, this is an unusual pattern for scrapers, which may be a sign of a more carnivorous diet in late ontogeny.
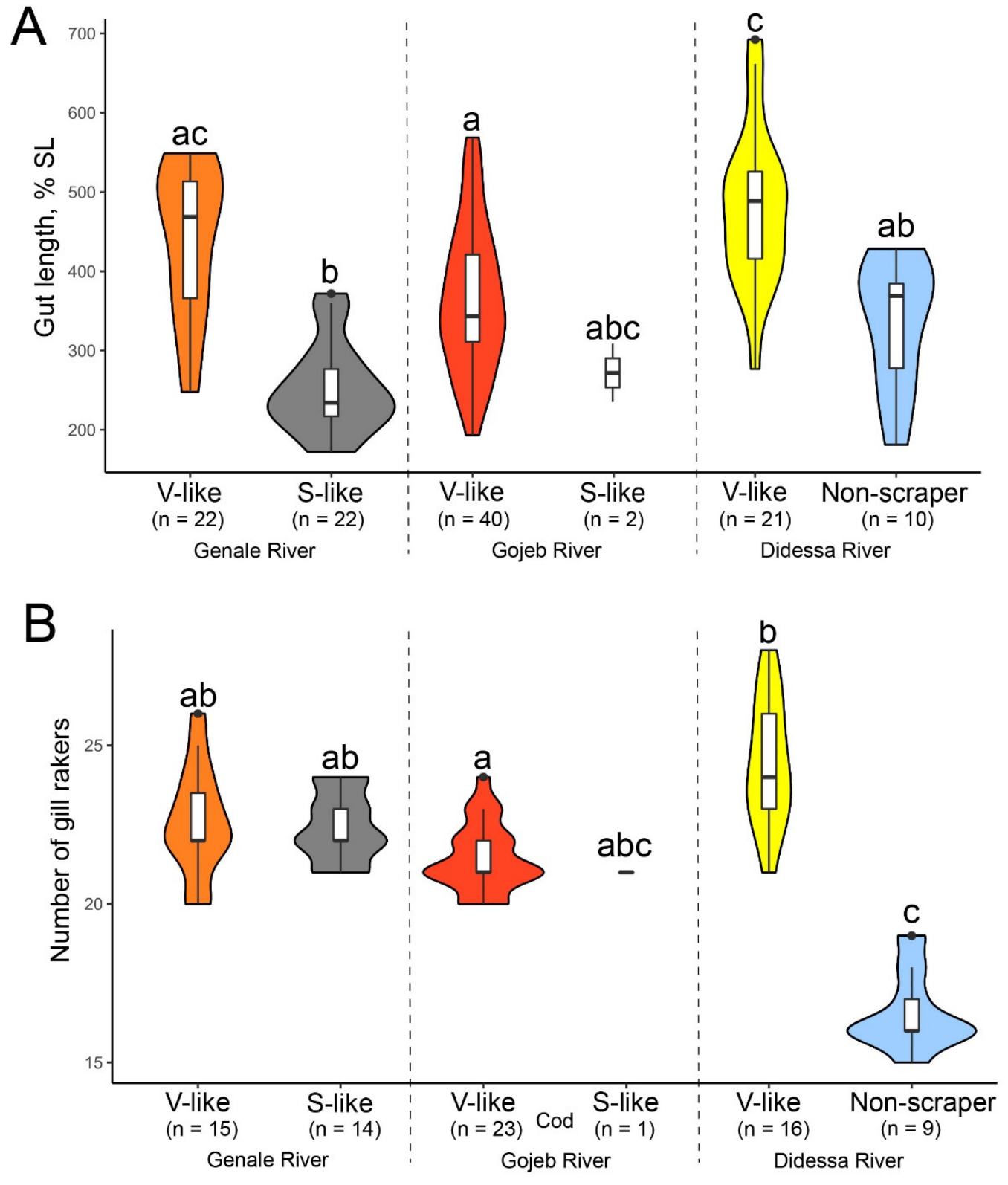

Figure 4. Violin plots of gut length (A) and gill raker numbers (B) regarding the distribution in scraper and non-scraper ecomorphs from the Genale, Gojeb and Didessa rivers. Min-max values (whiskers), 1st and 3rd quartiles (white vertical bars), median values (black horizontal bars), and outliers (black points) are indicated. Lowercase letters above the violin plots indicate significant differences between ecomorphs ( $p<0.05$, Kruskal-Wallis test with Dunn's post hoc test).

\subsection{Gill Rakers}

All scrapers had a high number of gill rakers (20-28) compared to the omnivorous ecomorphs (15-19) (Figure 4B). No difference between sympatric (or non-sympatric) V-like and S-like ecomorphs was detected in both the Genale and Gojeb rivers, while the V-like 
scraper from the Gojeb River had significantly lower gill raker numbers compared to the V-like samples from the Didessa $(p<0.05)$. The non-scraper, omnivorous ecomorph significantly differed from the scraper ecomorphs $(p<0.05)$, except for the S-like samples from the Gojeb River, by a lower range of gill raker numbers (Figure $4 \mathrm{~B}$ ).

\subsection{Diet}

The gut content was represented by invertebrates (mainly insects-Coleoptera, Diptera, Ephemeroptera, Heteroptera, Hymenoptera, Plecoptera, Trichoptera), macrophytes, periphyton, detritus, filamentous algae, and other sources (sporadically occurring Copepoda and Oligochaeta, along with unrecognizable half-digested particles). The six ecomorphs were characterized by four different diets, as estimated by IR values (Figure 5). The macrophytes strongly dominated the diet of V-like scrapers in both the Genale and Gojeb Rivers (IR $=97.6 \%$ and $86.4 \%$ respectively). We have to clarify that the term "macrophytes" in the rivers under consideration refers mainly to the remnants of helophytic and semi-aquatic plants, represented by seeds, leaves, stems, and flower parts, rarely coupled with filamentous algae. In this relation, we classify the types of the feeding of V-like scrapers from both the Genale and Gojeb rivers as herbivory-detritivory. The diet of S-like scrapers from both the Genale and Gojeb rivers remarkably differed from V-like scrapers, and mainly included insects (IR $=62 \%$ and $87 \%$, respectively). Their diet could be considered insectivorous. Along with insects, the detritus ( $\mathrm{IR}=24 \%$ and $8 \%$ ) and macrophytes (IR $=13 \%$ and $5 \%$ ) were also significant parts of the gut contents of S-like scrapers. The diet of the V-like scraper from the Didessa River was largely different from any other ecomorphs under consideration and consisted of periphyton ( $\mathrm{IR}=99 \%$ ) with occasional insects (Ephemeroptera and Diptera-Chironomidae and Simuliidae). The periphyton was composed of the algae Bacillariophyceae, Chlorophyta, and Desmidiales. The diet of the omnivorous ecomorph is different from all scrapers and is composed of detritus ( $I R=51 \%$ ) and insects ( $I R=49 \%$ ), represented by the larvae of amphibiotic Diptera, Ephemeroptera, and Trichoptera as well as imago of Hymenoptera (Figure 5).

\section{IR, \%}

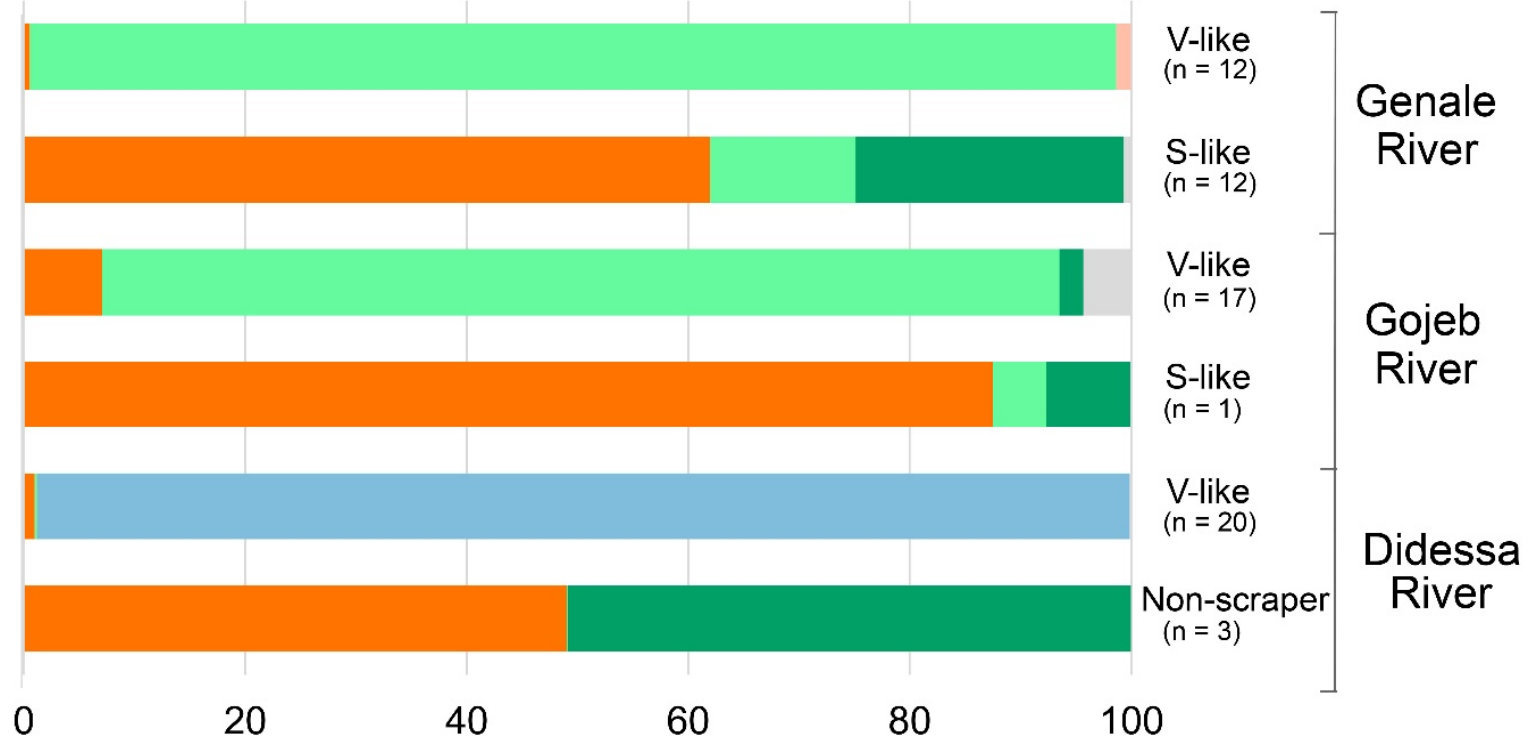

\section{Insects $\backsim$ Macrophytes $₫$ Periphyton $₫$ Detritus $₫$ Algae $₫$ Other}

Figure 5. Food spectrum (IR: the index of relative importance) of the five ecomorphs of scrapers and one ecomorph of the omnivorous barb of the genus Labeobarbus from three Ethiopian rivers. The category "Other" represents sporadically occurring Copepoda and Oligochaeta, along with half-digested unrecognizable food particles. 


\subsection{Stable Isotopes}

A significant difference in $\delta^{15} \mathrm{~N}$ values was detected between sympatric ecomorphs in all three rivers (Figure 6; $p<0.05$ ). The mean $\delta^{15} \mathrm{~N}$ values of $\mathrm{V}$-like and S-like scrapers from the Gojeb River differed by $2.1 \%$; this is close to the difference between adjacent trophic levels [61], while differences between analogous scraper ecomorphs in the Genale was only $0.7 \%$. No difference in the $\delta^{13} \mathrm{C}$ values between the V-like and S-like scrapers was detected in either the Genale or Gojeb rivers. The V-like scraper from the Didessa River had remarkably higher values of both $\delta^{15} \mathrm{~N}$ and $\delta^{13} \mathrm{C}$ than a sympatric omnivorous ecomorph (Figure 6; $p<0.05$ ). This scraper was also rich in ${ }^{13} \mathrm{C}$ compared to other ecomorphs.
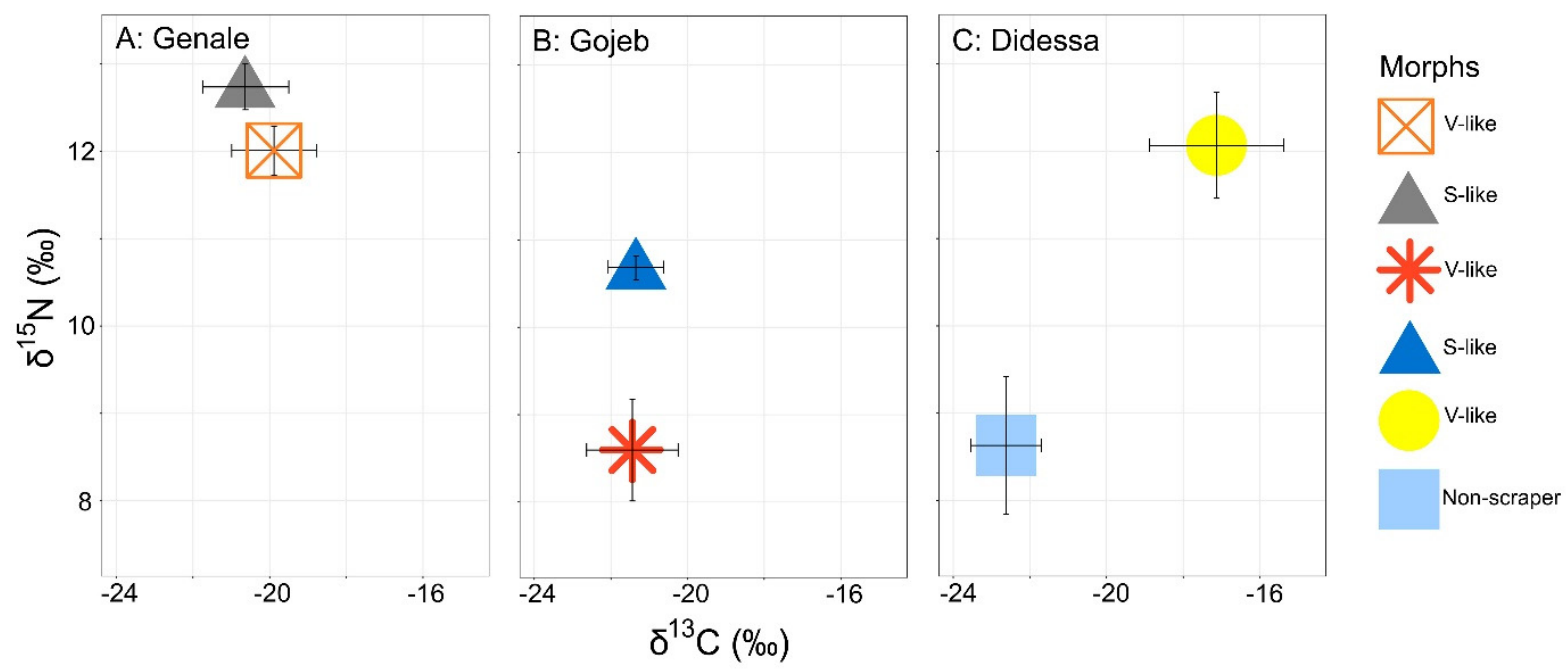

Figure 6. Biplots of stable isotope composition (mean $\delta^{13} \mathrm{C}$ and $\delta^{15} \mathrm{~N}$ values $\pm \mathrm{SD}$ ) of the sympatric V-like and S-like scraper ecomorphs from the Genale (A) and Gojeb (B) rivers, and V-like scraper and non-scraper (omnivorous) ecomorphs from the Didessa River $(\mathbf{C})$. All sympatric ecomorphs differed from each other in $\delta^{15} \mathrm{~N}$ values; $\delta^{13} \mathrm{C}$ values only differed in the Didessa River samples (Mann-Whitney U test, $p<0.05$; see details in the text).

\section{Discussion}

Our study revealed a diversification of ecological niches, based on the utilization of different trophic resources within fish having a scraping mouth phenotype, and often classified as "Varicorhinus"-like mouth labeobarbs (see [29]). Three different feeding types were revealed, based on a combination of ecological (diet and stable isotope composition) and morphological data. Although $\sim 40$ species/morphs of "Varicorhinus"-like labeobarbs were described throughout Africa [16,29], a phenomenon of trophic resource partitioning for this group was detected for the first time. Remarkably, a divergence of feeding strategies was revealed in the sympatric forms that suggests ecological niche separation during sympatric speciation. Similar divergences of ecological niches of scrapers have evolved repeatedly in two geographically isolated river basins, within genetically divergent lineages (see [16], for the genetics data) that provide an example of parallel ecological speciation. We consider the obtained results in more detail below.

\subsection{Trophic Resource Partitioning}

The three feeding modes detected among Ethiopian scrapers in this study are: (i) periphytonophagy, (ii) herbivory-detritivory, and (iii) insectivory. This amazing diversification in feeding type was discovered based on a combination of data from the diet analysis and stable isotope signatures and was accompanied by morpho-ecological data-head proportions and gut length, in particular. The gut length was repeatedly reported as indicative of diet in different fish lineages, e.g., cichlids, cyprinids, poeciliids, etc. [11,15,62,63]. Remarkably, three different feeding modes have evolved within one group of mouth-type, which is 
rather rare among specialists like the scrapers [26]. Further diversification of feeding types for sub-types is more often realized among the large-mouthed phenotype of Labeobarbus, which is represented by 8 different types of piscivorous Labeobarbus spp. in Lake Tana $[5,11]$ and by three types in the Didessa River [16,64]. It is the first, but predictably not the last, finding of niche diversification and trophic resource partitioning within a plethora of chisel-mouthed phenotypes of the widely distributed African genus Labeobarbus [29,65].

Although chisel-mouthed scrapers were heretofore presumably considered as periphyton feeders [27], only one of the five studied scrapers could be classified as periphytonophagous, while others had different feeding modes. A periphyton feeder detected in the rivers of the Ethiopian Highlands refers to L. beso, while other scraper ecomorphs belong to the L. gananensis complex (Genale River) and L. intermedius complex (Gojeb River) (see Levin et al., 2020) [16]. Remarkably, one periphyton feeder (L. beso) was rich in ${ }^{15} \mathrm{~N}$ $\left(\delta^{15} \mathrm{~N} 11.4-13.7 \%\right)$; this is comparable to sympatrically co-occurring piscivorous Labeobarbus $\left(\delta^{15} \mathrm{~N} 11.1-13.2 \%, \mathrm{n}=11\right.$, data not shown). It was also rich in ${ }^{13} \mathrm{C}$ compared to other ecomorphs (average $\delta^{13} \mathrm{C}=-17.1 \%$, Figure 6). Periphyton is a rich community composed of algae (mainly green algae and diatoms), detritus, bacteria, fungi, protists, zooplankton and other invertebrates hiding within algal mats [66]. Algal periphyton consumed by $L$. beso (Bacillariophyceae, Chlorophyta, and Desmidiales) is rather rich in proteins $[67,68]$. Elevated $\delta^{15} \mathrm{~N}$ values in L. beso may be considered as due to the possibility of utilizing protein-rich but not easily digested food, i.e., periphyton. We suppose that specialized periphyton feeders such as L. beso (see [45]) have a complex of morphological, physiological, biochemical and microbiome adaptations to successfully digest and utilize the periphyton food. This may explain why $L$. beso had $\delta^{15} \mathrm{~N}$ values equal to such sympatrically occurring piscivorous fish; however, this hypothesis should be tested further.

The evolution of periphytonophagous adaptations probably occurred over millions of years. Specialized lineages of periphitonophagous scrapers can be found among a type of Asian cyprinids of a rather old origin (Miocene), e.g., Capoeta (Valenciennes 1842), Cyprinion (Heckel 1843), Garra (Hamilton 1822), Onychostoma (Günther 1896), Scaphiodonichthys (Vinciguerra 1890), Schizothorax (Heckel 1838), Schizopygopsis (Steindachner 1866) [28,32,33]; however, note the exceptions in feeding specialization for some members of these genera $[17,26,69]$. In the case of chisel-mouthed fish, periphyton feeding is accompanied by morpho-ecological adaptations, such as modified jaws, a long gut with thin walls, increased gill raker numbers, and often a black peritoneum ([27,45], this study). This could be the result of a long evolution process, as is true for the Ethiopian periphyton feeder L. beso, which is the oldest branch among all Ethiopian Labeobarbus and is considered a relic of ancient adaptive radiation (see Levin et al., 2020).

The other four scraper ecomorphs of more recent origin (probably of Pleistocene origin-see Beshera et al. [70] are herbivores-detritivores or insectivores. Insectivory has not yet been reported for the Labeobarbus scrapers, although it is known for some representatives of evolutionarily distant lineages of scrapers, like Capoeta, Schizopygopsis, and Sarcocheilichthys (Bleeker 1860) [26,69,71,72]. It is noteworthy that the divergence of sympatric pairs of scrapers was confirmed in both the Genale and Gojeb rivers, not only by diet and stable isotope data but also by head morphology and gut length.

\subsection{Parallel Ecological Speciation among Ethiopian Labeobarbus Scrapers}

In our view, the main finding of our study is a sympatric eco-morphological divergence of scrapers into two different types (V-like and S-like) in a parallel manner, in two geographically isolated drainages within different evolutionary lineages-L. gananensis (Genale River) and L. cf. intermedius (Gojeb River). This suggests repeated and rapid adaptive radiation within scraping phenotypes since sympatric scrapers have little or no genetic differences between each other $[15,16]$. The parallel ecological divergence of scrapers, as reported in our study, is part of a more global system of repeated adaptive radiations within a lineage of Labeobarbus that evolved in water bodies of the Ethiopian Highlands $[5,6,15,16]$. The main features of this radiation are: (i) trophic resource partitioning that is mainly 
based on the diversification of mouth phenotypes-generalized, lipped, scraping, and large-mouthed; this was demonstrated for Lake Tana [5,11] and the Genale River [15]; (ii) parallelism in the origin of mouth phenotype polymorphism in genetically divergent lineages [16]; and (iii) further diversification of niches within certain mouth phenotype in some radiations-e.g., several types of large-mouthed phenotypes (piscivory feeding strategies- $[5,6,64]$, and scraping mouth phenotypes (this study). The adaptive radiation of fishes is often repeated (e.g., [73-78]. The origin of the scraping mouth phenotype is fairly parallel since most of the $\sim 40$ species/morphs have evolved independently within the Labeobarbus lineage [36,37]. Our study shows that further diversification of the scraping phenotype as a way to utilize the different trophic resources (ecological speciation) is possible, and that this is realized in a parallel route.

We consider the possibly lowered competition and relaxed natural selection in faunapoor mid-upper reaches of the rivers as a possible prerequisite for ongoing adaptive radiation of Labeobarbus in the waters of the Ethiopian Highlands [14-16]. In addition, the mid-upper reaches are characterized by the increased availability of ecological niches compared to the most-upper reach (i.e., more diverse ecotopes/habitats in this section offer more ecological opportunities, see [3]). The combination of these conditions (lower competition and diverse habitats) could promote adaptive radiation among the Ethiopian cyprinids [17].

Supplementary Materials: The following are available online at https:/ /www.mdpi.com/article/10 $.3390 / w 13172345 / s 1$, Figure S1: Pearson correlation of gut length and body length for ecomorphs from three separated basins; Table S1: Eigenvectors of 10 most loaded characters to Figure 3A; Table S2: Eigenvectors of 10 most loaded characters to Figure 3B; Table S3: Eigenvec-tors of 10 most loaded characters to Figure 3C.

Author Contributions: Conceptualization, B.A.L. and A.S.G.; methodology, B.A.L., A.S.K., O.L.R.; software, B.A.L.; validation, B.A.L. and A.S.G.; formal analysis, B.A.L. and A.S.K.; investigation, B.A.L., A.S.K., O.L.R., and A.S.G.; resources, B.A.L.; data curation, B.A.L., A.S.K., O.L.R.; writingoriginal draft preparation, B.A.L. and A.S.G.; writing—review and editing, B.A.L. and A.S.K.; visualization, B.A.L. and A.S.K.; supervision, B.A.L.; project administration, A.S.K.; funding acquisition, B.A.L. All authors have read and agreed to the published version of the manuscript.

Funding: This research was funded by the Russian Science Foundation, grant no. 19-14-00218: "Adaptive radiation and sympatric speciation in cyprinid fishes".

Institutional Review Board Statement: The study was conducted according to the guidelines of the Declaration of Helsinki, and approved by the Bioethics Committee of the Papanin Institute for Biology of Inland Waters (protocol code 3-26/3/21, date of approval 26 March of 2021).

Informed Consent Statement: Not applicable.

Data Availability Statement: The data presented in this study is available on request from the corresponding author.

Acknowledgments: Material for this study was collected within the scope of the Joint EthiopianRussian Biological Expedition (JERBE). We gratefully acknowledge the JERBE coordinators A.A. Darkov (Severtsov Institute of Ecology and Evolution, Moscow, Russia-IEE) and Simenew Keskes Melaku (Ministry of Innovation and Technology, Addis Ababa, Ethiopia) for administrative assistance. We express our gratitude to S.E. Cherenkov and Yu.Yu. Dgebuadze (both from IEE), Fekadu Tefera and Genanaw Tesfaye (both from the National Fishery and Other Aquatic Life Research Center of the Ethiopian Institute of Agricultural Research-EIAR, Sebeta), and M.V. Mina (Institute of Developmental Biology, Moscow, Russia) for sharing field operations and assistance in collecting material. We thank S.E. Cherenkov for his help with photography, and O.N. Artaev for creating the map. We acknowledge A.V. Tiunov for his valuable help during stable isotope analysis and discussion of the results.

Conflicts of Interest: The authors declare no conflict of interest. 


\section{References}

1. Schluter, D. The Ecology of Adaptive Radiation; Oxford University Press: New York, NY, USA, 2000.

2. Seehausen, O. African cichlid fish: A model system in adaptive radiation research. Proc. R. Soc. B Biol. Sci. 2006, $273,1987-1998$. [CrossRef]

3. Stroud, J.T.; Losos, J.B. Ecological opportunity and adaptive radiation. Ann. Rev. Ecol. Evol. Syst. 2016, 47, 507-532. [CrossRef]

4. Gillespie, R.G.; Bennett, G.M.; De Meester, L.; Feder, J.L.; Fleischer, R.C.; Harmon, L.J.; Wogan, G.O. Comparing adaptive radiations across space, time, and taxa. J. Hered. 2020, 111, 1-20. [CrossRef] [PubMed]

5. Nagelkerke, L.A.J.; Sibbing, F.A.; van den Boogaart, J.G.M.; Lammens, E.H.R.R.; Osse, J.W.M. The barbs (Barbus spp.) of Lake Tana: A forgotten species flock? Env. Biol. Fish. 1994, 39, 1-22. [CrossRef]

6. Mina, M.V.; Mironovsky, A.N.; Dgebuadze, Y. Lake Tana large barbs: Phenetics, growth and diversification. J. Fish Biol. 1996, 48, 383-404. [CrossRef]

7. Nagelkerke, L.A.J.; Sibbing, F.A. Reproductive segregation among the large barbs (Barbus intermedius complex) of Lake Tana, Ethiopia. An example of intralacustrine speciation? J. Fish. Biol. 1996, 49, 1244-1266. [CrossRef]

8. de Graaf, M.; Megens, H.-J.; Samallo, J.; Sibbing, F.A. Evolutionary origin of Lake Tana's (Ethiopia) small Barbus species: Indications of rapid ecological divergence and speciation. Anim. Biol. 2007, 57, 39-48. [CrossRef]

9. de Graaf, M.; Dejen, E.; Osse, J.W.M.; Sibbing, F.A. Adaptive radiation of Lake Tana's (Ethiopia) Labeobarbus species flock (Pisces, Cyprinidae). Mar. Freshw. Res. 2008, 59, 391-407. [CrossRef]

10. Dimmick, W.W.; Berendzen, P.B.; Golubtsov, A.S. Genetic comparison of three Barbus (Cyprinidae) morphotypes from the Genale River, Ethiopia. Copeia 2001, 4, 1123-1129. [CrossRef]

11. Sibbing, F.A.; Nagelkerke, L.A.J. Resource partitioning by Lake Tana barbs predicted from fish morphometrics and prey characteristics. Rev. Fish. Biol. Fisher. 2001, 10, 393-437. [CrossRef]

12. Stiassny, M.L.J.; Getahun, A. An overview of labeonin relationships and the phylogenetic placement of the Afro-Asian genus Garra Hamilton, 1822 (Teleostei: Cyprinidae), with the description of five new species of Garra from Ethiopia, and a key to all African species. Zool. J. Linn. Soc. 2007, 150, 41-83. [CrossRef]

13. Golubtsov, A.S.; Cherenkov, S.E.; Tefera, F. High morphological diversity of the genus Garra in the Sore River (the White Nile Basin, Ethiopia): One more cyprinid species flock? J. Ichthyol. 2012, 52, 817-820. [CrossRef]

14. Golubtsov, A.S.; Korostelev, N.B.; Levin, B.A. Monsters with a shortened vertebral column: A population phenomenon in radiating fish Labeobarbus (Cyprinidae). PLoS ONE 2021, 16, e0239639. [CrossRef]

15. Levin, B.A.; Casal-López, M.; Simonov, E.; Dgebuadze, Y.Y.; Mugue, N.S.; Tiunov, A.V.; Doadrio, I.; Golubtsov, A.S. Adaptive radiation of barbs of the genus Labeobarbus (Cyprinidae) in an East African river. Freshw. Biol. 2019, 64, 1721-1736. [CrossRef]

16. Levin, B.A.; Simonov, E.; Dgebuadze, Y.Y.; Levina, M.; Golubtsov, A.S. In the rivers: Multiple adaptive radiations of cyprinid fishes (Labeobarbus) in Ethiopian Highlands. Sci. Rep. 2020, 10, 7192. [CrossRef]

17. Levin, B.; Simonov, E.; Franchini, P.; Mugue, N.; Golubtsov, A.; Meyer, A. Adaptive radiation and burst speciation of hillstream cyprinid fish Garra in African river. Mol. Ecol. 2021, in press. [CrossRef]

18. Nikolskii, G.V. The Ecology of Fishes; Academic Press: London, UK, 1963.

19. Wootton, R.J. Ecology of Teleost Fishes; Chapman \& Hall: London, UK, 1990.

20. Bănărescu, P.; Coad, B.W. Cyprinids of Eurasia. In Cyprinid Fishes; Winfield, I.J., Nelson, J.S., Eds.; Chapman \& Hall: London, UK, 1991; pp. 127-155. [CrossRef]

21. Skelton, P.H.; Tweddle, D.; Jackson, P.B.N. Cyprinids of Africa. In Cyprinid Fishes; Winfield, I.J., Nelson, J.S., Eds.; Chapman \& Hall: London, UK, 1991; pp. 211-239. [CrossRef]

22. Mayden, R.L. Cyprinids of the New World. In Cyprinid Fishes; Winfield, I.J., Nelson, J.S., Eds.; Chapman \& Hall: London, UK, 1991; pp. 240-263. [CrossRef]

23. Howes, G. Anatomy and evolution of the jaws in the semiplotine carps with a review of the genus Cyprinion Hechel, 1843 (Teleostei: Cyprinidae). Bull. Nat. Hist. Mus. Zool. 1982, 42, 299-335.

24. Chen, Y.-Y. Anatomy and evolution of the jaws in the semiplotine carps with a review of the genus Onychostoma Günther, 1896. Bull. Nat. Hist. Mus. Zool. 1989, 42, 299-335.

25. Nikolskii, G.V. Special Ichthyology: Israel Program for Scientific Translation; Today \& Tomorrow Printers \& Publishers: New Delhi, India, 1989.

26. Komarova, A.S.; Rozanova, O.L.; Levin, B.A. Trophic resource partitioning by sympatric ecomorphs of Schizopygopsis (Cyprinidae) in a young Pamir Mountain lake: Preliminary results. Ichthyol. Res. 2021, 68, 191-197. [CrossRef]

27. Matthes, H. A comparative study of the feeding mechanisms of some African Cyprinidae (Pisces, Cypriniformes). Bijdr. Dierk. 1963, 33, 3-35. [CrossRef]

28. Levin, B.A.; Freyhof, J.; Lajbner, Z.; Perea, S.; Abdoli, A.; Gaffaroğlu, M.; Özuluğ, M.; Rubenyan, H.R.; Salnikov, V.B.; Doadrio, I. Phylogenetic relationships of the algae scraping cyprinid genus Capoeta (Teleostei: Cyprinidae). Mol. Phylogenet. Evol. 2012, 62, 542-549. [CrossRef]

29. Vreven, E.J.; Musschoot, T.; Snoeks, J.; Schliewen, U.K. The African hexaploid Torini (Cypriniformes: Cyprinidae): Review of a tumultuous history. Zool. J. Linn. Soc. 2016, 177, 231-305. [CrossRef] 
30. Vreven, E.J.; Musschoot, T.; Decru, E.; Wamuini Lunkayilakio, S.; Obiero, K.; Cerwenka, A.F.; Schliewen, U.K. The complex origins of mouth polymorphism in the Labeobarbus (Cypriniformes: Cyprinidae) of the Inkisi River basin (Lower Congo, DRC, Africa): Insights from an integrative approach. Zool. J. Linn. Soc. 2019, 186, 414-482. [CrossRef]

31. Lammens, E.H.R.R.; Hoogenboezem, W. Diets and feeding behaviour. In Cyprinid Fishes; Winfield, I.J., Nelson, J.S., Eds.; Chapman \& Hall: London, UK, 1991; pp. 353-376. [CrossRef]

32. Yang, L.; Arunachalam, M.; Sado, T.; Levin, B.A.; Golubtsov, A.S.; Freyhof, J.; Friel, J.P.; Chen, W.J.; Hirt, M.V.; Manickam, R.; et al. Molecular phylogeny of the cyprinid tribe Labeonini (Teleostei: Cypriniformes). Mol. Phylogenet. Evol. 2012, 65, 362-379. [CrossRef] [PubMed]

33. Yang, L.; Sado, T.; Hirt, M.V.; Pasco-Viel, E.; Arunachalam, M.; Li, J.; Wang, X.; Freyhof, J.; Saitoh, K.; Simons, A.M.; et al. Phylogeny and polyploidy: Resolving the classification of cyprinine fishes (Teleostei: Cypriniformes). Mol. Phylogenet. Evol. 2015, 85, 97-116. [CrossRef] [PubMed]

34. Lévêque, C.; Daget, J. Cyprinidae. In Check-List of the Freshwater Fishes of Africa. CLOFFA 1; Daget, J., Gosse, J.-P., Thys van den Audenaerde, D.F.E., Eds.; ISNB: Bruxelles, Belgium; MRAC: Tervuren, Belgium; ORSTOM: Paris, France, 1984; pp. $217-342$.

35. Froese, R.; Pauly, D. (Eds.) FishBase: Stockholm, Sweden, 2021. Available online: www.fishbase.org (accessed on 21 March 2021).

36. Tsigenopoulos, C.S.; Kasapidis, P.; Berrebi, P. Phylogenetic relationships of hexaploid large-sized barbs (genus Labeobarbus, Cyprinidae) based on mtDNA data. Mol. Phylogenet. Evol. 2010, 56, 851-856. [CrossRef] [PubMed]

37. Levin, B.A.; Golubtsov, A.S.; Dgebuadze, Y.Y.; Mugue, N.S. New evidence of homoplasy within the African genus Varicorhinus (Cyprinidae): An independent origin of specialized scraping forms in the adjacent drainage systems of Ethiopia inferred from mtDNA analysis. Afr. Zool. 2013, 48, 400-406. [CrossRef]

38. Eschmeyer, W.N.; Fricke, R.; van der Laan, R. (Eds.) Catalog of Fishes: Genera, Species, References. 2021. Available online: http:/ / researcharchive.calacademy.org/research/ichthyology/catalog/fishcatmain.asp (accessed on 28 June 2021).

39. Oellermann, L.K.; Skelton, P.H. Hexaploidy in yellowfish species (Barbus, Pisces, Cyprinidae) from southern Africa. J. Fish Biol. 1990, 37, 105-115. [CrossRef]

40. Golubtsov, A.S.; Krysanov, E.Y. Karyological study of some cyprinid species from Ethiopia. The ploidy differences between large and small Barbus of Africa. J. Fish Biol. 1993, 42, 445-455. [CrossRef]

41. Guégan, J.-F.; Rab, P.; Machordom, A.; Doadrio, I. New evidence of hexaploidy in 'large' African Barbus with some considerations on the origin of hexaploidy. J. Fish Biol. 1995, 47, 192-198. [CrossRef]

42. Krysanov, E.Y.; Golubtsov, A.S. Karyotypes of some Ethiopian Barbus and Varicorhinus from the Nile Basin including Lake Tana morphotypes. Folia Zool. 1996, 45 (Suppl. 1), 67-75.

43. Naran, D.; Skelton, P.H.; Villet, M.H. Karyology of three evolutionarily hexaploid southern African species of yellowfish, Labeobarbus Rüppell, 1836 (Cyprinidae). Afr. Zool. 2007, 42, 254-260. [CrossRef]

44. Mina, M.V.; Mironovsky, A.N.; Golubtsov, A.S.; Dgebuadze, Y.Y. The 'Barbus' intermedius species flock in Lake Tana (Ethiopia): II-Morphological diversity of" large barbs" from Lake Tana and neighbouring areas: Homoplasies or synapomorphies? Ital. J. Zool. 1998, 65 (Suppl. 1), 9-14. [CrossRef]

45. Levin, B.A. New data on morphology of the African scraping feeder Varicorhinus beso (Osteichthyes: Cyprinidae) with the special reference to specialized traits. J. Ichthyol. 2012, 52, 908-923. [CrossRef]

46. Banister, K. Three new species of Varicorhinus (Pisces, Cyprinidae) from Africa. Bull. Nat. Hist. Mus. Zool. 1984, 47, $273-282$.

47. Reid, G.M. A Revision of African Species of Labeo and Re-Definition of the Genus; Verlag von J. Cramer: Braunschweig, Germany, 1985.

48. Golubtsov, A.S.; Dgebuadze, Y.Y.; Mina, M.V. Fishes of the Ethiopian Rift Valley. In Ethiopian Rift Valley Lakes; Tudorancea, C., Taylor, W.D., Eds.; Backhuys Publishers: Leiden, The Netherlands, 2002; pp. 167-258.

49. Mironovsky, A.N.; Mina, M.V.; Dgebuadze, Y.Y. Large African barbs with hypertrophied lips and their relationship with generalized forms of species of the genus Barbus (Labeobarbus auctorum). J. Ichthyol. 2019, 59, 327-335. [CrossRef]

50. Hubbs, C.L.; Lagler, K.F. Fishes of the Great Lakes Region; Michigan University Press: Ann Arbor, MI, USA, 1958.

51. Levin, B.A.; Rubenyan, A.R.; Salnikov, V.B. Phenetic diversity of khramulya Capoeta capoeta (Ostariophysi, Cyprinidae). J. Ichthyol. 2005, 45, 754-767.

52. Mina, M.V.; Levin, B.A.; Mironovsky, A.N. On the possibility of using character estimates obtained by different operators in morphometric studies of fish. J. Ichthyol. 2005, 45, 284-294.

53. Natarajan, A.V.; Jhingran, A.G. Index of preponderance-A method of grading the food elements in the stomach analysis of fishes. Indian J. Fish. 1961, 8, 54-59.

54. Popova, O.A.; Reshetnikov, Y.S. On Complex Indices in Investigation of Fish Feeding. J. Ichthyol. 2011, 51, 686-691. [CrossRef]

55. Post, D.M.; Layman, C.A.; Arrington, D.A.; Takimoto, G.; Quattrochi, J.; Montana, C.G. Getting to the fat of the matter: Models, methods and assumptions for dealing with lipids in stable isotope analyses. Oecologia 2007, 152, 179-189. [CrossRef]

56. RStudio Team. RStudio: Integrated Development for R; RStudio: PBC, Boston, MA, USA; Available online: http:/ / www.rstudio.com (accessed on 20 March 2021).

57. Comtois, D. Summarytools: Tools to Quickly and Neatly Summarize Data. R Package Version 0.8. 72018. 2018. Available online: https:/ /CRAN.R-project.org/package=summarytools (accessed on 20 March 2021).

58. Wickham, H. Ggplot2: Elegant Graphics for Data Analysis; Springer: Berlin/Heidelberg, Germany, 2016.

59. Pohlert, T.; Pohlert, M.T. Package 'PMCMR'. R Package Version. 2018. Available online: https://cran.r-project.org/web/packages/ PMCMR/index.html (accessed on 13 August 2021). 
60. Ogle, D.; Ogle, M.D. Package 'FSA'. CRAN Repos. 2017. Available online: https://cran.microsoft.com/snapshot/2017-08-14 /web/packages/FSA/FSA.pdf (accessed on 13 August 2021).

61. McCutchan, J.H., Jr.; Lewis, W.M., Jr.; Kendall, C.; McGrath, C.C. Variation in trophic shift for stable isotope ratios of carbon, nitrogen, and sulfur. Oikos 2003, 102, 378-390. [CrossRef]

62. Wagner, C.E.; McIntyre, P.B.; Buels, K.S.; Gilbert, D.M.; Michel, E. Diet predicts intestine length in Lake Tanganyika's cichlid fishes. Funct. Ecol. 2009, 23, 1122-1131. [CrossRef]

63. Zandonà, E.; Auer, S.K.; Kilham, S.S.; Reznick, D.N. Contrasting population and diet influences on gut length of an omnivorous tropical fish, the Trinidadian guppy (Poecilia reticulata). PLoS ONE 2015, 10, e0136079. [CrossRef]

64. Golubtsov, A.S. Fish 'Species Flocks' in Rivers and Lakes: Sympatric Divergence in Poor Fauna Fish Communities as Particular Modus of Evolution. In Relevant Problems of Contemporary Ichthyology (To 100 Jubilee of G. V. Nikolsky); Pavlov, D.S., Dgebuadze, Y.Y., Shatunovsky, M.I., Eds.; KMK Scientific Press: Moscow, Russia, 2010; pp. 96-123.

65. Kisekelwa, T.; Snoeks, J.; Zamba, A.I.; Amzati, G.S.; Isumbisho, M.; Masilya, P.M.; Lemmens, P.; Vreven, E. Association between Labeobarbus spp. (Teleostei: Cyprinidae) and environmental variables in the Luhoho basin (Eastern Congo River basin; DRC). J. Fish Biol. 2021. [CrossRef] [PubMed]

66. Azim, M.E.; Beveridge, M.C.M.; van Dam, A.A.; Verdegem, M.C. Periphyton and aquatic production: An introduction. In Periphyton: Ecology, Exploitation and Management; Azim, M.E., Verdegem, M.C.J., van Dam, A.A., Beveridge, M.C.M., Eds.; Centre for Agriculture and Bioscience International: Wallingford, UK, 2005; pp. 1-13.

67. Becker, E.W. Micro-algae as a source of protein. Biotechnol. Adv. 2007, 25, 207-210. [CrossRef] [PubMed]

68. Saikia, S.K. Review on periphyton as mediator of nutrient transfer in aquatic ecosystems. Ecol. Balk. 2011, 3, 65-78.

69. Akin, S.; Turan, H.; Kaymak, N. Does diet variation determine the digestive tract length of Capoeta banarescui Turan, Kottelat, Ekmekci and Imamoglu, 2006. J. Appl. Ichthyol. 2016, 32, 883-892. [CrossRef]

70. Beshera, K.A.; Harris, P.M.; Mayden, R.L. Novel evolutionary lineages in Labeobarbus (Cypriniformes; Cyprinidae) based on phylogenetic analyses of mtDNA sequences. Zootaxa 2016, 4093, 363-381. [CrossRef]

71. Nikolskii, G.V. Special Ichthyology; Sov. Nauka: Moscow, Russia, 1950.

72. Popov, A.V. Morphofunctional adaptations of the Pamir Schizopygopsis stolizkai Steind. in lake Yashil-kul. Vopr Ikhtiol 1968, 8, 15-30. (In Russian)

73. Thompson, C.E.; Taylor, E.B.; McPhail, J.D. Parallel evolution of lake-stream pairs of threespine sticklebacks (Gasterosteus) inferred from mitochondrial DNA variation. Evolution 1997, 51, 1955-1965. [PubMed]

74. Rüber, L.; Verheyen, E.; Meyer, A. Replicated evolution of trophic specializations in an endemic cichlid fish lineage from Lake Tanganyika. Proc. Nat. Acad. Sci. USA 1999, 96, 10230-10235. [CrossRef] [PubMed]

75. Alekseyev, S.S.; Samusenok, V.P.; Matveev, A.N.; Pichugin, M.Y. Diversification, sympatric speciation, and trophic polymorphism of Arctic charr, Salvelinus alpinus complex, in Transbaikalia. Env. Biol. Fish. 2002, 64, 97-114. [CrossRef]

76. Derome, N.; Bernatchez, L. The transcriptomics of ecological convergence between 2 limnetic coregonine fishes (Salmonidae). Mol. Biol. Evol. 2006, 23, 2370-2378. [CrossRef]

77. Elmer, K.R.; Fan, S.; Kusche, H.; Luise Spreitzer, M.; Kautt, A.F.; Franchini, P.; Meyer, A. Parallel evolution of Nicaraguan crater lake cichlid fishes via non-parallel routes. Nat. Commun. 2014, 5, 5168. [CrossRef]

78. Burress, E.D.; Holcomb, J.M.; Bonato, K.O.; Armbruster, J.W. Body size is negatively correlated with trophic position among cyprinids. R. Soc. Open Sci. 2016, 3, 150652. [CrossRef] 